\author{
(online) $=$ ISSN $2285-3642$ \\ ISSN-L = 2285 - 3642 \\ Journal of Economic Development, Environment and People \\ Volume 5, Issue 2, 2016 \\ URL: http://jedep.spiruharet.ro \\ e-mail: office jedep@spiruharet.ro
}

\title{
Basics and Alternatives Concerning the Measurement of Company Performances
}

\author{
Cicilia Ionescu ${ }^{1}$, Cornel Ionescu ${ }^{2}$ \\ ${ }^{1,2}$ Spiru Haret University Bucharest, Romania
}

\begin{abstract}
In a competitive economy, a company's activity aims to achieve strategic objectives. Of these, two objectives: making profit and meeting the needs of a particular market segment are vital targets to maintaining the company's market position. This requires information which reveals the company's financial position and profitability. The companies which want to be competitive must assess the company's capacity to generate positive results and cash in a reliable way. This strategy needs information on the resources used and the results obtained, but should not overlook the truth that the profit arises from uncertainty and the risk assumed by the entrepreneur. In this regard, the International Accounting Standards often use the term "probability" when referring to the recognition criteria of structures comprised in the financial statements.
\end{abstract}

Keywords: internal control, accounting information, decision making process, utility noncompliance, credibility, accounting principles.

Jel Codes: $M 40, M 42$

\section{Introduction}

Accounting information regarding the outcome of the company can be build and communicated to users through two types of financial statements: the balance sheet and profit and loss. The balance sheet ascertains the result in the form of profit or loss, as the variation of company wealth determined by its activity during a fiscal year, whereas profit or loss describes and explains the result through the structure of expenditure and revenues that have resulted.

\footnotetext{
${ }^{1}$ Email address: cicilia.ionescu@yahoo.com

${ }^{2}$ Email address: caragea21@yahoo.com
} 


\author{
(online) $=$ ISSN $2285-3642$ \\ ISSN-L = $2285-3642$ \\ Journal of Economic Development, Environment and People \\ Volume 5, Issue 2, 2016 \\ URL: $\underline{\text { http://jedep.spiruharet.ro }}$ \\ e-mail: office jedep@spiruharet.ro
}

The complementarity of the two synthesis documents, to which is also added the statement of changes in financial position, we find formulated in the "Framework for the Preparation and Presentation of Financial Statements", developed by the IASB.

Thus, "information about the financial position are primarily offered by the balance sheet. Information about the results are provided primarily by the income statement. Information about changes in the financial position are provided by financial statements through a separate statements. Components of the financial statements interrelate because they reflect different aspects of the same transactions or events. Although each situation offers different information, it is possible that either do not serve a single purpose ... "(Framework for the Preparation and Presentation of Financial Statements-IASB, par. 19, 20).

The most used model to reflect the performance of companies is profit and loss account. The informational value of this financial situations component lies in the fact that it renders performance to the company, meaning it indicates the degree to which it has achieved the objectives connected to profit making. In the profit and loss account appear flows which determine the outcome, understandable in principle, as changes in equity capital during a fiscal year.

Defining company performance is, however done in different ways, depending on the users' interest, principles, conventions and adopted accounting rules for determining the result. This is what experts in the field call accounting policies.

The question which arises, however, is how accurate can the outcome determined by the profit and loss account be? The answer can only be a relative one. If the elaboration of the profit and loss account is made by specialists, in good faith, the results can be as realistic as possible. If they resort to methods, techniques, tools, aimed at the favorable presentation of the financial position and performance of the company, the results can be distorted.

One should understand that the calculated result of the profit and loss account can be relative, not exact, its size also depends on the applicable accounting methods offered by the accounting treatments and policies recommended by international accounting standards.

The existence of several possible options in accounting, corresponding either to some genuine accounting choices, or to a freedom of appreciation in the context of individual or consolidated financial statements presentation, can influence company performance.

We present below some of the accepted calculation alternatives, according to international accounting rules concerning the elements of financial statements and their impact on the company's performance image.

\title{
2. Accounting Alternatives Related to the Stock Acquisition Cost
}

Usually, the stock acquisition cost includes: the purchase price; import duties and other taxes (except those which the company can recover from the tax authorities); freight and handling costs; other costs directly attributable to the acquisition of finished goods, materials and services. Depending on the management's option, stock acquisition costs can be different, in the sense of including or not the freight costs. Considering this, the final result will be different too. 


\author{
(online) $=$ ISSN $2285-3642$ \\ ISSN-L = 2285 - 3642 \\ Journal of Economic Development, Environment and People \\ Volume 5, Issue 2, 2016 \\ URL: http://jedep.spiruharet.ro \\ e-mail: office jedep@spiruharet.ro
}

Example:

A company purchases goods under the following conditions: purchase price of goods is 37.260 .000 lei, freight costs are 8.197.200 lei; revenues from the sale of goods are 74.520.012 lei. The company manager may choose to include freight costs in the acquisition cost or not, thus leading to different accounting results.

Excerpt from the profit and loss account

\begin{tabular}{|c|r|r|}
\hline \multicolumn{1}{|c|}{ Elements } & $\begin{array}{c}\text { Transport costs are } \\
\text { included in the acquisition } \\
\text { cost }\end{array}$ & $\begin{array}{c}\text { Transport costs are not } \\
\text { included in the acquisition } \\
\text { cost }\end{array}$ \\
\hline Revenue from the sale of goods & 74.520 .012 & $\mathbf{7 4 . 5 2 0 . 0 1 2}$ \\
\hline Expenditure for sold goods & $(45.494 .460)$ & $37.297 .260)$ \\
\hline - acquisition cost & 37.260 .000 & -260.000 \\
\hline -freight costs & 8.197 .200 & 37.260 \\
\hline - handling costs & 37.260 & $\mathbf{3 7 . 2 2 2 . 7 5 2}$ \\
\hline Accounting Result & $\mathbf{2 9 . 0 2 5 . 5 5 2}$ & \\
\hline
\end{tabular}

The company's decision to include freight costs in the acquisition cost leads to a different/lower result/profit, than the one which doesn't include these freight costs.

\title{
3. Capitalization of borrowing costs on stocks
}

The cost of stocks may also include the cost of borrowing. Capitalization of borrowing costs is stipulated by IAS 23 "Borrowing Costs" by the allowed alternative accounting treatment, valid for stocks that require a substantial period of time to get ready for use or sale.

Example:

During the fiscal year $\mathrm{N}$, the company acquires finished products at the cost of production of 10.100.000 lei (excluding interest). The interest charged by the bank is 3.030 .000 lei. The result will be different, depending on the company's decision to capitalize or not the interest expenses. Through the capitalization of interest expenses, the company performance is substantially improved.

The application of the afore mentioned accounting treatments has the following impact on the profit and loss account:

Excerpt from the profit and loss account

\begin{tabular}{|l|r|r|}
\hline \multicolumn{1}{|c|}{ Elements } & Interest is capitalized & \multicolumn{1}{c|}{ Interest is not capitalized } \\
\hline Turnover & 615.198 .070 & 615.198 .070 \\
\hline Change in stocks & 13.130 .000 & 10.100 .000 \\
\hline $\begin{array}{l}\text { Raw materials and consumables } \\
\text { expenses }\end{array}$ & $(109.115 .350)$ & $(109.115 .350)$ \\
\hline Salary and social expenses & $(242.061 .650)$ & $(242.061 .650)$ \\
\hline
\end{tabular}


(online) = ISSN $2285-3642$

ISSN-L = $2285-3642$

Journal of Economic Development, Environment and People

Volume 5, Issue 2, 2016

URL: http://jedep.spiruharet.ro

e-mail: office jedep@spiruharet.ro

\begin{tabular}{|l|r|r|}
\hline Other operating expenses & $(174.331 .050)$ & $(174.331 .050)$ \\
\hline Operational result & 102.820 .020 & 102.820 .020 \\
\hline Interest expenses & - & $(3.030 .000)$ \\
\hline Accounting result & $\mathbf{1 0 2 . 8 2 0 . 0 2 0}$ & $\mathbf{9 9 . 7 9 0 . 0 2 0}$ \\
\hline
\end{tabular}

Including interest expenses in the stock acquisition costs, distorts the real image of the company, determining an increase of 3.030 .000 lei to the accounting result.

\section{Accounting Alternatives Related to Subsequent Expenditures to Commissioning Tangible Assets}

Subsequent expenditure on an item such as land and fixed assets, which has already been recognized, should be added to the carrying amount of the asset only when it is estimated that the company will benefit economically in the future, in addition to the performance initially estimated as being suitable.

Example:

The company renovated the building where the administrative department operates, at the start of the fiscal year N. The building was purchased 18 years ago, at an input value of 500.000 lei, the useful life being 20 years. Renovation expenses were 40.804 .000 lei.

Managers appreciate the building has a high degree of deterioration, therefore its restoration being necessary, in order to provide further functionality. The proposed solution is not to capitalize renovation costs. What will be the impact on the result?

Excerpt from the profit and loss account

\begin{tabular}{|l|r|r|}
\hline \multirow{2}{*}{ Elements } & \multicolumn{2}{|c|}{ N } \\
\cline { 2 - 3 } & \multicolumn{2}{|c|}{ Renovation expenses } \\
\cline { 2 - 3 } & Are Capitalized & Are not capitalized \\
\hline Turnover & 615.198 .070 & 615.198 .070 \\
\hline Renovation expenses & - & $(40.804 .000)$ \\
\hline Amortization expenses & $(45.450)$ & $(25.250)$ \\
\hline $\begin{array}{l}\text { Raw materials and consumables } \\
\text { expenses }\end{array}$ & $(109.115 .350)$ & $(109.115 .350)$ \\
\hline Salary and social expenses & $(242.061 .650)$ & $(242.061 .650)$ \\
\hline Other operating expenses & $(174.331 .050)$ & $(174.331 .050)$ \\
\hline Total Expenses & $(525.553 .500)$ & $(566.337 .300)$ \\
\hline Accounting result & $\mathbf{8 9 . 6 4 4 . 5 7 0}$ & $\mathbf{4 8 . 8 6 0 . 7 7 0}$ \\
\hline
\end{tabular}




\author{
(online) $=$ ISSN $2285-3642$ \\ ISSN-L = $2285-3642$ \\ Journal of Economic Development, Environment and People \\ Volume 5, Issue 2, 2016 \\ URL: http://jedep.spiruharet.ro \\ e-mail: office jedep@spiruharet.ro
}

\title{
5. Accounting Alternatives Related to Amortization Expenses of Tangible Assets
}

The depreciable amount of an asset should be allocated systematically throughout the useful life of that asset. Typically, the depreciation method chosen is one that reflects the pace at which future economic benefits are consumed as a result of the use of the asset. Companies avail themselves of the opportunity to choose from different methods of amortization, thus leading, most of the times to different results.

Example:

At 31.12.2013, the company purchased a means of transport, with the entry value of 500.000 lei and the useful life of 10 years. For systematic allocation of the means of transport, company managers can use either the linear amortization method, the digressive one or the accelerated one.

The situation of the amortization expenses determined by the three methods and reflected in the income and loss account for the year 2014, is as follows:

- Linear amortization expense $=500.000 \times 10 \%=50.000$ lei

- Digressive amortization expense $=500.000 \times 20 \%=100.000$ lei

- Accelerated amortization expense $=500.000 \times 50 \%=250.000$ lei

Excerpt from the profit and loss accountof the fiscal year (2014)

\begin{tabular}{|l|r|r|r|}
\hline \multicolumn{1}{|c|}{ Elements } & Linear amortization & \multicolumn{1}{c|}{$\begin{array}{c}\text { Digressive } \\
\text { amortization }\end{array}$} & \multicolumn{1}{c|}{$\begin{array}{c}\text { Accelerated } \\
\text { amortization }\end{array}$} \\
\hline Turnover & 615.198 .070 & 615.198 .070 & 615.198 .070 \\
\hline Amortization expenses & $(50.000)$ & $(100.000)$ & $(250.000)$ \\
\hline $\begin{array}{l}\text { Raw materials and } \\
\text { consumables expenses }\end{array}$ & $(109.115 .350)$ & $(109.115 .350)$ & $(109.115 .350)$ \\
\hline Salary and social expenses & $(242.061 .650)$ & $(242.061 .650)$ & $(242.061 .650)$ \\
\hline Other operating expenses & $(174.331 .050)$ & $(174.331 .050)$ & $(174.331 .050)$ \\
\hline Accounting result & $\mathbf{8 9 . 6 4 0 . 0 2 0}$ & $\mathbf{8 9 . 5 9 0 . 0 2 0}$ & $\mathbf{8 9 . 4 4 0 . 0 2 0}$ \\
\hline
\end{tabular}

Choosing the linear amortization method creates the image of a more efficient company. It is a misleading image because during the 2015 fiscal year, the situation changes as follows:

The situation of amortization in 2015:

- Linear amortization expense $=500.000 \times 10 \%=50.000$ lei

- Digressive amortization expense $=400.000 \times 20 \%=80.000$ lei

- Accelerated amortization expense $=250.000 \times 11 \%=27.500$ lei 


\author{
(online) $=$ ISSN $2285-3642$ \\ ISSN-L = 2285 - 3642 \\ Journal of Economic Development, Environment and People \\ Volume 5, Issue 2, 2016 \\ URL: http://jedep.spiruharet.ro \\ e-mail: office jedep@spiruharet.ro
}

Excerpt from the profit and loss accountof the fiscal year (2015)

\begin{tabular}{|l|r|r|r|}
\hline \multicolumn{1}{|c|}{ Elements } & Linear amortization & \multicolumn{1}{c|}{$\begin{array}{c}\text { Digressive } \\
\text { amortization }\end{array}$} & $\begin{array}{r}\text { Accelerated } \\
\text { amortization }\end{array}$ \\
\hline Turnover & 615.198 .070 & 615.198 .070 & 615.198 .070 \\
\hline Amortization expenses & $(50.000)$ & $(80.000)$ & $(27.500)$ \\
\hline $\begin{array}{l}\text { Raw materials and } \\
\text { consumables expenses }\end{array}$ & $(109.115 .350)$ & $(109.115 .350)$ & $(109.115 .350)$ \\
\hline Salary and social expenses & $(242.061 .650)$ & $(242.061 .650)$ & $(242.061 .650)$ \\
\hline Other operating expenses & $(174.331 .050)$ & $(174.331 .050)$ & $(174.331 .050)$ \\
\hline Accounting result & $\mathbf{8 9 . 6 4 0 . 0 2 0}$ & $\mathbf{8 9 . 6 7 0 . 0 2 0}$ & $\mathbf{8 9 . 7 2 2 . 5 2 0}$ \\
\hline
\end{tabular}

Unlike 2014, when the ideal amortization method was the linear one, during 2015 the accelerated method improves company performance.

\title{
6. Accounting Alternatives Related to Tangible Assets Revaluation
}

Although the process of tangible assets revaluation is at first glance an ordinary one, this technique can distort the company's performance. Finding themselves in difficulty, many companies resort to using this type of accounting engineering, as a last chance to performance improvement reflected by the statement of changes in equity capital.

Example:

A company owns an industrial warehouse which was purchased at a value of 800.000 lei; the amortization value is 200.000 lei. The remaining useful life is 10 years and the amortization method is linear. Company managers decide at the beginning of 2010 fiscal year, to reassess the asset, its fair value being 900.000 lei. The revaluation reserve will be 300.000 lei (900-600). The company's performance before and after revaluation, as evidenced by the statement of changes in equity capital is:

\begin{tabular}{|l|r|r|}
\hline \multicolumn{1}{|c|}{ Elements } & Before revaluation & After revaluation \\
\hline Subscribed capital & 296.892 .000 & 296.892 .000 \\
\hline Revaluation reserves & 122.794 .000 & 123.094 .000 \\
\hline Total equity capital & $\mathbf{4 1 9 . 6 8 6 . 0 0 0}$ & $\mathbf{4 1 9 . 9 8 6 . 0 0 0}$ \\
\hline
\end{tabular}

Revaluation of depreciable assets has the effect of increasing amortization expenses, and therefore a reduction of the result.

Annual amortization before revaluation is 60.000 lei $(600.000 \times 10 \%)$, and after revaluation it is 90.000 lei $(900.000 \times 10 \%)$. Thus, the result is decreased by 30.000 lei after revaluation: 


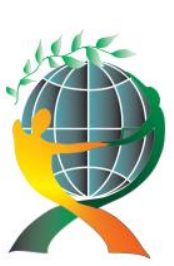

\author{
(online) $=$ ISSN $2285-3642$ \\ ISSN-L = 2285 - 3642 \\ Journal of Economic Development, Environment and People \\ Volume 5, Issue 2, 2016
}

URL: $\underline{\text { http://jedep.spiruharet.ro }}$

e-mail: office jedep@spiruharet.ro

\begin{tabular}{|l|r|r|}
\hline \multicolumn{1}{|c|}{ Elements } & Before revaluation & \multicolumn{1}{c|}{ After revaluation } \\
\hline Turnover & 615.198 .070 & 615.198 .070 \\
\hline Amortization expenses & $(60.000)$ & $(90.000)$ \\
\hline $\begin{array}{l}\text { Raw materials and consumables } \\
\text { expenses }\end{array}$ & $(109.115 .350)$ & $(109.115 .350)$ \\
\hline Salary and social expenses & $(242.061 .650)$ & $(242.061 .650)$ \\
\hline Other operating expenses & $(174.331 .050)$ & $(174.331 .050)$ \\
\hline Accounting result & $\mathbf{8 9 . 6 3 0 . 0 2 0}$ & $\mathbf{8 9 . 6 0 0 . 0 2 0}$ \\
\hline
\end{tabular}

To counteract the decrease of the result, companies prefer to reassess non-depreciable assets. To overcome the impediment of a lower result, one can also use the attribution of revaluation capital gains on revaluation reserves.

\title{
7. Conclusions
}

The long term survival of a company depends on its ability to generate a profit which is at least satisfactory. Investors become and remain shareholders in a company if they consider that dividends and other capital income they will receive will be higher than the income from other investments with similar risk levels. In this context, the profit, as absolute profitability indicator, is both a business premise and a consequence.

Therefore, assessing the quality of the profit achieved should be an ongoing concern for both the company management as well as for the analyst making the assessment. Freedom of choice regarding accounting policies by company management is one of the main informational limitations to the profit and loss account. Moreover, in practice there are cases in which accountants, relying on the power conferred by existing rules to make estimates and forecasts or those allowed alternative accounting treatments, actually resort to some creative accounting techniques which are often at the borderline of current laws and regulations.

To ensure good faith in applying accounting treatments, accounting must have rules and proper tools in order to provide reasonable assurance that they are applied fairly and honestly. Here comes the role of internal control. At present, internal control is treated as an essential process in achieving the objectives of a company and thus accounting. Through the financial reporting framework, the concept of "internal accounting and financial control "as "a major element of internal control" which provides accounting and financial monitoring, is introduced. It also provides the communication of accounting and financial information in decision-making processes and contributes to the development of "reliable and consistent information, according to legal requirements" (OMFP no. 1802/2014). The lack of adequate internal control can lead to distorted reports. 


\author{
(online) $=$ ISSN $2285-3642$ \\ ISSN-L = $2285-3642$ \\ Journal of Economic Development, Environment and People \\ Volume 5, Issue 2, 2016 \\ URL: http://jedep.spiruharet.ro \\ e-mail: office jedep@spiruharet.ro
}

\title{
8. References
}

[1] Cicilia, Ionescu - Contabilitate, baze si proceduri, FRM Publishing House, Bucharest, 2008

[2] Cicilia, Ionescu- Contabilitatea în fața provocărilor ingineriilor financiare, Economie teoretică şi aplicată, anul XIII, nr. 5 (500), iulie 2006

[3] Cicilia, Ionescu, Floarea, Georgescu - Harmonization of accounting in the process of globalization of economic activities, Jurnal of Economic Development, Environment and People, Vol. 3, No 1 (2014).

[4] Cicilia, Ionescu- Informarea financiară în contextul internaționalizării contabilității, Economica Publishing House, Bucharest, 2003

[5] Cornel IONESCU, Cicilia IONESCU - Internal Control - Crucial Factor in Ensuring the Quality of Financial Information, Procedia of Economics and Business Administration, 2015

[6] Ştefănescu, A. "Performanța financiară a întreprinderii între realitate şi creativitate", Economica Publishing House, Bucharest, 2005

[7] Ghid practic de aplicare a reglementărilor contabile conforme cu Directivele Europene aprobate prin Ordinul Ministrului Finanțelor Publice nr. 3055/2009, C.E.C.C.A.R. Publishing House, Bucharest, 2010

[8] Standardele Internaționale de Raportare Financiară (IFRS ${ }^{\circledR}$ ) - Norme oficiale emise la 1 ianuarie 2011, Partea A, Cadrul general conceptual şi dispoziții, C.E.C.C.A.R. Publishing House, Bucharest, 2011

[9] OMFP 1802/2014, Partea I, pentru aprobarea Reglementărilor contabile privind situațiile financiare anuale individuale şi situațiile financiare anuale consolidate, M.O. 963/30 dec. 2014

***IAS 2 ,Stocurile”

***IAS 16, Imobilizările corporale

***IAS 23, Costurile indatorării 